Gut, 1978, 19, 14-18

\title{
Effect of secretogogues on mucosal blood flow in the antrum and corpus of the stomach
}

\author{
T. V. TAYlOR, B. R. PUllan, J. GODDARD, AND B. TORRANCE \\ From the Departments of Gastroenterology and Medical Physics, Royal Infirmary, Manchester
}

SUMMARY Gastric mucosal blood flow in the rat was determined by the indicator fractionation technique of Sapirstein using $\mathrm{Rb}^{86} \mathrm{Cl}$. Antral and corpus flow rates were determined in response to increasing doses of pentagastrin and histamine and the effect of vagotomy was determined. With progressive stimulation the antral:corpus flow ratio increased with both stimulants; however, vagotomy and noradrenaline reduced blood flow in both areas of mucosa. It is concluded that the antrum, as well as the corpus, actively responds to secretory stimulants by an increase in mucosal blood flow and support is provided for the theory that the antrum plays an active role in the control of parietal cell blood flow and secretion.

The effect of secretory stimulants on gastric mucosal blood flow has been investigated by several groups of workers-notably, Jacobson et al. (1966b), who determined a marked rise in gastric blood flow in response to histamine in the canine stomach and Reed and Smy (1971) have shown a similar response to pentagastrin in the cat; both these groups of workers using the aminopyrine clearance technique. Little work has been done on the relationship between antral and corpus blood flow in response to these agents; however, a relationship between antral and parietal cell mucosal flow has been postulated by Menguy (1962) and Waddell and Williams (1959).

Delaney and Grim (1965) using the isotope $\mathrm{K}^{42} \mathrm{Cl}$ presented evidence that the indicator fractionation technique of Sapirstein (1957) provides an accurate measure of gastric blood flow and its distribution to individual areas of the stomach. The aim of this study was to investigate the effect of increasing doses of secretogogues on mucosal blood flow to the antrum and corpus of the rat stomach using $\mathrm{Rb}^{86} \mathrm{Cl}$. The effect of vagotomy and of the direct physiological stimulus of food has also been assessed.

\section{Methods}

Wistar rats weighing between 150 and $225 \mathrm{~g}$ were fasted for 48 hours before experimentation, free access to water being allowed. An intraperitoneal injection of pentagastrin (Peptavlon, ICI) or histamine was given in the varying doses $(6 \mu \mathrm{g} / \mathrm{kg}-100$

Received for publication 2 September 1977 $\mu \mathrm{g} / \mathrm{kg}$ pentagastrin, $\quad 0.04 \mathrm{mg} / \mathrm{kg}-0.08 \mathrm{mg} / \mathrm{kg}$ histamine) and 30 minutes later the animals were lightly anaesthetised with a mixture of halothane, nitrous oxide, and oxygen. Eight rats were included in each dosage group; in one group a truncal vagotomy was performed three days before experimentation and in one group noradrenaline was given $(1 \mathrm{ml}$ of $1: 100,000)$ intraperitoneally.

Sapirstein (1957) studied the fractional distribution of the radioactive indicator $\mathrm{Rb}^{86} \mathrm{Cl}$ and related its clearance from the blood stream to adjacent tissues to regional blood flow. After intravenous injection of the isotope in the rat, arterial blood concentrations were studied by Sapirstein as a function of time. It was found that the tissue concentration of the isotope reached a stable level in all organs other than the brain in six to nine seconds and maintained this level for 64 seconds. The arterial concentration curves for the isotope in different anatomical situations showed that the injected dose was almost completely transferred from the arterial system to the adjacent tissues within six to nine seconds, the extraction ratio being approximately equal to 1 . The rat has a circulation time of less than one minute and organs displayed stability of activity during the 64 seconds.

Initially, this hypothesis was confirmed in the present study. A lead shield with a 'window' cut in it was placed over various parts of an anaesthetised rat (Fig. 1). A sodium iodide scintillation counter was placed over this window and the amount of irradiation within the window was transmitted to a recording device. $\mathrm{Rb}^{86} \mathrm{Cl}(100 \mu \mathrm{Ci})$ was given through the 


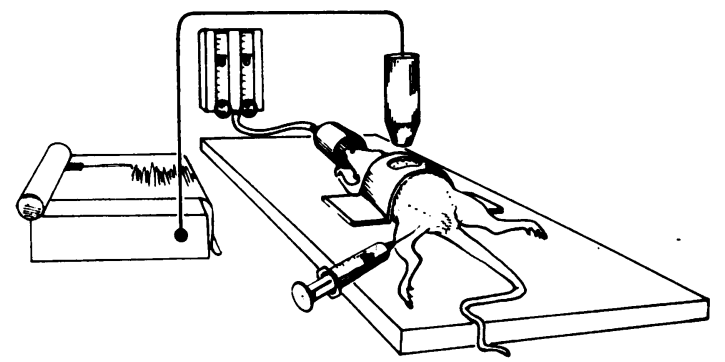

Fig. 1 Experimental model designed to validate the indicator fractionation technique of Sapirstein.

femoral vein and within 10 seconds the amount of radioactivity was raised to a maximum level which remained stable up to 64 seconds. Positioning of the window over different parts of the body did not appreciably affect the form of the tracing. The fraction of the total injected isotope contained in an organ during the time of a stable count is assumed to be equal to the fraction of the cardiac output perfusing that organ.

Into one femoral vein $100 \mu \mathrm{Ci}$ of $\mathrm{Rb}^{86} \mathrm{Cl}$ was given over a 10 second period and 40 seconds later the animal was killed with a rapid injection of $0.5 \mathrm{ml}$ KC1 $(1 \mathrm{mmol} / \mathrm{ml})$ administered via the opposite femoral vein. As the concentration of isotope in all organs other than the brain remains constant between 10 and 60 seconds the exact timing is not critical but $\mathbf{4 0}$ seconds is within the first circulation in the rat. The stomach was immediately removed and opened along the greater curvature, the distribution of isotope having been frozen by arresting the circulation. Specimens were gently blotted and the mucosa was removed from the antrum and corpus by a blunt glass microscopic slide, over $90 \%$ of the mucosa can be obtained in this way (Touloukian and Spencer, 1972). Each specimen was accurately weighed and counted in a gamma counter and the total remaining rat was also counted in the same counter. As we were measuring variations in mucosal blood flow from animal to animal and antral corpus flow ratios in the same animal, individual cardiac outputs were not measured, but were compensated for by expressing the fraction of total radioactivity delivered to the mucosal tissues. This method of assessment has been used by Touloukian and Spencer (1972). The calculation was carried out accordingly:

$$
\frac{\text { Uptake by mucosa }}{\text { Uptake by total rat tissue }}=\frac{\text { Blood flow to organ }}{\text { Cardiac output }}
$$

$\frac{\text { Uptake per } \mathrm{g} \text { of mucosa }}{\text { Uptake per } \mathrm{g} \text { of rat tissue }}=$

$$
\begin{gathered}
\frac{\text { Blood flow/g of sample }}{\text { Cardiac output/g of rat tissue }} \\
\frac{\text { Blood flow per } \mathrm{g} \text { of mucosa }}{\text { Blood flow per g of total rat tissue }} \\
\frac{\text { Activity in mucosa }}{\text { Activity in whole rat }} \times \frac{\text { Rat weight }}{\text { Mucosal weight }}
\end{gathered}
$$

This gives an expression for the blood flow to the gastric mucosa as a fraction of the average flow to a gram of rat tissue; the use of the resulting dimensionless unit makes it possible to compare mucosal blood flow from one animal to another without measuring individual cardiac outputs; blood flow accordingly is expressed below in 'units'. Stated more simply, the fraction of the total injected dose of isotope in the gastric mucosa is the fraction of cardiac output delivered to that mucosa.

\section{ASSESSMENT OF GASTRIC MUCOSAL BLOOD VOLUME}

In this study the isotope used was $I^{\mathbf{1 2 5}}$ serum albumin which, in the short term, apart from some extraction by the liver, remains intravascular. After complete mixing of this isotope has taken place within the circulation, the quantity of radioactivity within the antral and corpus mucosa relative to each other would be an index of the ratio of blood volumes within the two areas. Thus, if five minutes were allowed after injection of the isotope, the relative quantities of radioactivity within the body and antrum of the stomach per gram of mucosal tissue would be indicative of their relative blood volumes. The modes of anaesthesia and of killing the rat, together with the conditions of counting, were exactly the same as in the earlier part of the study. Sixteen rats were studied under basal conditions and two groups of six rats were given intraperitoneal pentagastrin and histamine respectively.

\section{Results}

The rates of blood flow to the antral and corpus mucosa with varying forms of stimulation and inhibition are shown in Tables 1 to 4 . These units express the blood flow per gram of wet mucosa and although the results show higher antral than corpus flow rates, when allowance is made for the increased amount of mucosal tissue in the parietal area (approximately four times the weight of the antral mucosa), the total blood flow through the corpus is between two and three times as great as antral blood flow.

From basal levels of blood flow obtained after 48 hours of fasting the rates of flow increased progressively with doses from $6 \mu \mathrm{g} / \mathrm{kg}$ to $50 \mu \mathrm{g} / \mathrm{kg}$. The 
Table 1 Effect of food and fasting on gastric mucosal blood flow

\begin{tabular}{llll}
\hline & $\begin{array}{l}\text { Mean of } 8 \\
\text { recordings } \\
\text { (units) }\end{array}$ & $\begin{array}{l}\text { Standard } \\
\text { deviation }\end{array}$ & $\begin{array}{l}\text { Standard } \\
\text { error }\end{array}$ \\
\hline Basal conditions & & & \\
(48 h fasting) & & & \\
Antral flow & 3.24 & 1.36 & 0.48 \\
Corpus flow & 2.35 & 0.88 & 0.31 \\
After food & & & \\
(stomach full) & & & \\
$\quad \begin{array}{l}\text { Antral flow } \\
\text { Corpus flow }\end{array}$ & 11.21 & 2.79 & 0.99 \\
After vagotomy & 7.09 & 2.48 & 0.87 \\
Food stimulated & & & \\
(stomach full) & & & \\
$\quad$ Antral flow & & 0.59 & 0.24 \\
$\quad$ Corpus flow & 8.41 & 0.62 & 0.25 \\
\hline
\end{tabular}

Table 2 Effect of increasing doses of pentagastrin on mucosal blood flow

\begin{tabular}{|c|c|c|c|c|}
\hline $\begin{array}{l}\text { Dose of } \\
P G \\
(m g / k g)\end{array}$ & Flow & $\begin{array}{l}\text { Mean of } 8 \\
\text { recordings } \\
\text { (units) }\end{array}$ & $\begin{array}{l}\text { Standard } \\
\text { deviation }\end{array}$ & $\begin{array}{l}\text { Standard } \\
\text { error }\end{array}$ \\
\hline 6 & $\begin{array}{l}\text { Antral } \\
\text { Corpus }\end{array}$ & $\begin{array}{l}5 \cdot 23 \\
3 \cdot 75\end{array}$ & $\begin{array}{l}1 \cdot 75 \\
0.71\end{array}$ & $\begin{array}{l}0.62 \\
0.25\end{array}$ \\
\hline 12 & $\begin{array}{l}\text { Antral } \\
\text { Corpus }\end{array}$ & $\begin{array}{l}5 \cdot 14 \\
4 \cdot 46\end{array}$ & $\begin{array}{l}0.67 \\
0.81\end{array}$ & $\begin{array}{l}0.21 \\
0.29\end{array}$ \\
\hline 18 & $\begin{array}{l}\text { Antral } \\
\text { Corpus }\end{array}$ & $\begin{array}{l}6 \cdot 31 \\
4 \cdot 56\end{array}$ & $\begin{array}{l}1 \cdot 81 \\
1 \cdot 15\end{array}$ & $\begin{array}{l}0.64 \\
0.41\end{array}$ \\
\hline 24 & $\begin{array}{l}\text { Antral } \\
\text { Corpus }\end{array}$ & $\begin{array}{l}7.91 \\
6.56\end{array}$ & $\begin{array}{l}1 \cdot 32 \\
0.74\end{array}$ & $\begin{array}{l}0.47 \\
0.26\end{array}$ \\
\hline 36 & $\begin{array}{l}\text { Antral } \\
\text { Corpus }\end{array}$ & $\begin{array}{l}7 \cdot 87 \\
5 \cdot 75\end{array}$ & $\begin{array}{l}1.53 \\
0.90\end{array}$ & $\begin{array}{l}0.54 \\
0.32\end{array}$ \\
\hline 50 & $\begin{array}{l}\text { Antral } \\
\text { Corpus }\end{array}$ & $\begin{array}{l}9 \cdot 56 \\
6 \cdot 67\end{array}$ & $\begin{array}{l}2 \cdot 40 \\
2 \cdot 81\end{array}$ & $\begin{array}{l}0.90 \\
1.05\end{array}$ \\
\hline 100 & $\begin{array}{l}\text { Antral } \\
\text { Corpus }\end{array}$ & $\begin{array}{l}7 \cdot 15 \\
6 \cdot 65\end{array}$ & $\begin{array}{l}2 \cdot 09 \\
3 \cdot 78\end{array}$ & $\begin{array}{l}0 \cdot 74 \\
1 \cdot 13\end{array}$ \\
\hline
\end{tabular}

Table 3 Effect of histamine on gastric mucosal blood flow

\begin{tabular}{lllll}
\hline $\begin{array}{l}\text { Dose } \\
(\mathrm{mg} / \mathrm{kg})\end{array}$ & Flow & $\begin{array}{l}\text { Mean of 6 } \\
\text { recordings } \\
(\text { units })\end{array}$ & $\begin{array}{l}\text { Standard } \\
\text { deviation }\end{array}$ & $\begin{array}{l}\text { Standard } \\
\text { error }\end{array}$ \\
\hline 0.08 & Antral & 12.84 & 2.33 & 0.95 \\
& Corpus & 7.52 & 0.98 & 0.40
\end{tabular}

Table 4 Significance values between increasing doses of pentagastrin and between food and fasting

\begin{tabular}{lll}
\hline $\begin{array}{l}\text { Dose } \\
(\mu g)\end{array}$ & $P($ Antrum) & $P($ Body $)$ \\
\hline 6 and 12 & $<0.45$ & $<0.10$ \\
6 and 18 & $<0.15$ & $<0.10$ \\
6 and 24 & $<0.005$ & $<0.005$ \\
6 and 36 & $<0.005$ & $<0.0025$ \\
6 and 50 & $<0.005$ & $<0.0005$ \\
Food and fasting & $<0.0005$ & $<0.0025$ \\
\hline
\end{tabular}

mean basal flow rate in the antrum was 3.24 units and in the corpus 2.35 units rising to 9.56 and 6.67 units respectively after $50 \mu \mathrm{g} / \mathrm{kg}$ pentagastrin, the greater increase in antral blood flow being observed in response to all stimulants. The maximum flow rate recorded was almost three times the basal levels in both parts of the stomach and rose quite steadily with each dose used (Tables 1 and 2). Higher doses than $50 \mu \mathrm{g} / \mathrm{kg}$ resulted in a reduction in blood flow with a wider scatter of results, possibly because of cardiovascular and respiratory irregularities produced by these doses. The dose response curve for pentagastrin is shown in Fig. 2.

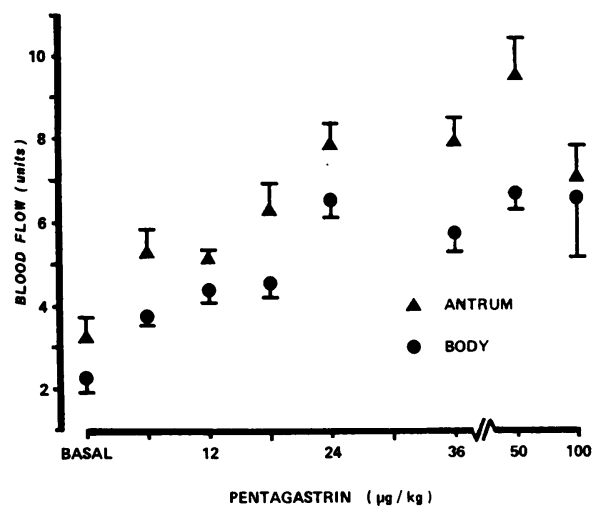

Fig. 2 The effect of increasing doses of pentagastrin on mucosal flow in the antrum and body of the stomach. (Blood flow is expressed in units per $g$ of mucosa).

Histamine produced a marked increase in mucosal blood flow to both the parietal cell area and the antrum of the stomach, the basal flow rates being more than trebled in response to a dose of $0.08 \mathrm{mg} / \mathrm{kg}$ (Table 3).

When the recordings were made within 30 minutes of eating a meal the mean blood flow was markedly higher than the fasting levels (Table 1), the values lying between those for the maximal response to histamine and that to pentagastrin (Fig. 3). Vagotomy reduced the response to a meal and noradrenaline decreased flow rates to approximately $60 \%$ of the physiological basal flow, markedly reducing the antral:body flow from 1.4 to $1 \cdot 0$ :1.In the vagotomised group the mean antral flow rate was 8.01 units, the corpus flow rate was 6.85 units, and in response to noradrenaline the corresponding recordings were 1.89 and 1.84 (Table 1).

GASTRIC MUCOSAL BLOOD VOLUME

The mean ratio of the volume of blood in the corpus to the antral mucosa was 2.06:1 (SD-0.34) under basal conditions. After pentagastrin the body:antral 


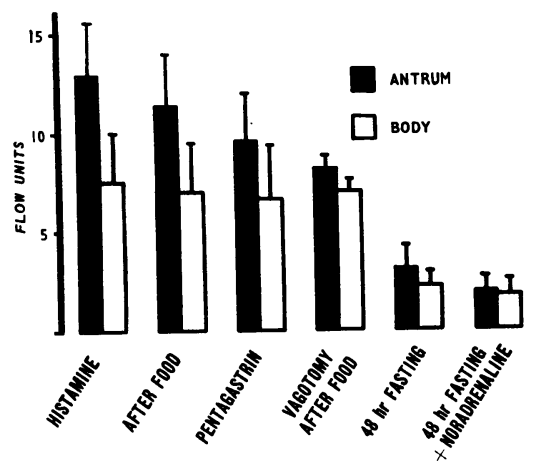

Fig. 3 A comparison of the effects of various extrinsic agents on gastric mucosal blood flow in the antrum and corpus. (Blood flow is expressed in units per $g$ of mucosa).

ratio was $2 \cdot 15: 1(\mathrm{SD}-0 \cdot 24)$ and after histamine the corresponding ratio was $2 \cdot 12: 1$ (SD-0.22). There was no statistical difference in these ratios after the stimulants and presumably any direct effect on the volume of the microvasculature produced by these substances was reflected equally in the corpus and antrum.

\section{Discussion}

The response to pentagastrin observed here is similar to that recorded in the cat by Reed and Smy (1971), who using the aminopyrine clearance technique to measure gastric mucosal blood flow found the maximal clearance in response to pentagastrin was about two and a half times the basal level. These workers also found that histamine produced higher levels of blood flow than pentagastrin, as did injections of crude pyloric gastrin extract. Jacobson (1964) has shown that porcine gastrin increased total gastrin blood, but Haigh et al. (1967) found only a transient increase in total gastric blood flow in response to intravenously administered pentagastrin in anaesthetised dogs, using the venous effluent technique.

Rudick et al. (1965) using electromagnetic flowmeters showed that porcine gastrin ' $\mathrm{g}$ ' produced an increase in total gastric blood flow which persisted for two hours. Swan and Jacobson (1967) employing the aminopyrine clearance technique in conscious dogs found that intravenous administration of pentagastrin produced an increase in mucosal flow at doses between $0.5 \mu \mathrm{g} / \mathrm{kg} / \mathrm{h}$ and $1 \mu \mathrm{g} / \mathrm{kg} / \mathrm{h}$, but at doses greater than this the flow rate tended to return to lower levels as in the above experiments. The effect of pentagastrin on conscious and anaesthetised dogs varied considerably, higher rates being recorded in conscious animals and it has been shown that acid secretion is reduced by anaesthesia (Schachter, 1949). The acid secretory response to pentagastrin in the rat is less marked than that in man, large doses being required to produce maximal secretion (Ganguli and Simpson, 1968).

The mechanism by which pentagastrin increases gastric blood flow may be different from that due to histamine stimulation; whereas the latter is known to have a direct effect on the microvasculature, the former appears to have a later and lesser effect. Although it has been suggested that increased blood flow in response to pentagastrin is secondary to increased acid secretion, the findings in this study of an increase in antral blood flow which is greater than that in the body of the stomach are against the above theory and in favour of a more direct vascular response.

Although Delaney and Grim (1965) measuring $\mathrm{K}^{42} \mathrm{Cl}$ clearance in dogs found that intravenous histamine had no effect on gastric mucosal blood flow, Menguy (1962) found a brisk response using the surface counting technique of Sevelius and Johnson (1959). He injected $\mathrm{I}^{125}$ albumin into the left gastric artery and monitored antrum and fundus with separate collimated scintillation counters, suggesting that gastric blood flow was predominantly antral and first postulated the antral control of gastric blood flow.

The reduction in blood flow recorded in response to noradrenaline (Fig. 2) is of a similar order to that recorded by Jacobson et al. (1966a) using the aminopyrine clearance technique in dogs. The reduction in flow rates after food produced by vagotomy lends further support to a relationship between gastric blood flow and acid output. Nylander and Olerud (1961) suggested that in the rat vagotomy produced an opening of submucosal arteriovenous anastomoses consequently reducing mucosal blood flow.

The relatively greater increase in antral blood flow is of interest. While total mucosal blood flow through the corpus is about three times that through the antrum, the flow rates per gram of mucosa in the antrum were greater than those in the corpus and the antral:corpus flow ratios increased with stimulation. The enhanced antral blood flow produced by the stimulation in this study suggests that the antrum is actively involved in the microvascular response. These findings give support to the proposals of Waddell and Williams (1959) and Menguy (1962) that the antrum may be concerned in the control of gastric blood flow and to the suggestion that the microvasculature of the antrum and corpus are intimately linked (Taylor and Torrance, 1975). 


\section{References}

Delaney, J. P., and Grim, E. (1965). Canine gastric blood flow and its distribution. American Journal of Physiology, 207, 1195-1202.

Ganguli, P. C., and Simpson, C. M. (1968). The dose-response relationship between pentapeptide (ICI 50123) and acidpepsin secretion in conscious rats (Abstract). Journal of Physiology, 198, 35p-36p.

Haigh, A. L., Moffitt, J. A., and Steedman, W. M. (1967). The action of a synthetic gastrin-like peptide (ICI 50,123) on gastric blood flow and acid secretion in the dog (Abstract). Journal of Physiology (Lond.), 191, 45p-46p.

Jacobson, E. D. (1964). Hemodynamic effects of bradykinin and gastrin in the stomach. American Heart Journal, 68, 214-219.

Jacobson, E. D., Eisenberg, M. M., and Swan, K. G. (1966a). Effects of histamine on gastric blood flow in conscious dogs. Gastroenterology, 51, 466-472.

Jacobson, E. D., Linford, R. H., and Grossman, M. I. (1966b). Gastric secretion in relation to mucosal blood flow studied by a clearance technique. Journal of Clinical Investigation, 45, 1-13.

Menguy, R. (1962). Effects of histamine on gastric blood flow. American Journal of Digestive Diseases, 7, 383-393.

Nylander, G., and Olerud, S. (1961). The vascular pattern of the gastric mucosa of the rat following vagotomy. Surgery, Gynecology and Obstetrics, 112, 475-480.
Reed, J. D., and Smy, J. R. (1971). Mechanisms relating gastric acid secretion and mucosal blood flow during gastrin and histamine stimulation. Journal of Physiology, 219, 571-585.

Rudick, J., Semb, L. S., Guntheroth, W. G., Mullins, G. L., Harkins, H. N., and Nyhus, L. M. (1965). Gastric blood flow and acid secretion in the conscious dog under various physiological and pharmacological stimuli. Surgery, 58, 47-57.

Sapirstein, L. A. (1958). Regional blood flow by the fractional distribution of indicators. American Journal of Physiology, 193, 161-168.

Schachter, M. (1949). Anaesthesia and gastric secretion. American Journal of Physiology, 156, 248-255.

Sevelius, G., and Johnson, P. C. (1959). Myocardial blood flow determined by surface counting and ratio formula. Journal of Clinical and Laboratory Medicine, 54, 669-679.

Swan, K. G., and Jacobson, E. D. (1967). Gastric blood flow and secretion in conscious dogs. American Journal of Physiology, 212, 891-896.

Taylor, T. V., and Torrance, H. B. (1975). Is there an antralbody portal system in the stomach? Gut, 16, 781-784.

Touloukian, R. J., and Spencer, R. P. (1972). Ileal blood flow preceding compensatory intestinal hypertrophy. Annals of Surgery, 175, 320-325.

Waddell, W. R., and Williams, H. W., Jr. (1959). The effect of antrectomy on gastric blood flow. Annals of Surgery, 150, 529-537. 